\title{
Receptor binding specificity and sequence comparison of a novel avian-origin H7N9 virus in China
}

\author{
Wei Hu \\ Department of Computer Science, Houghton College, Houghton, USA \\ Email:wei.hu@houghton.edu
}

Received 16 April 2013; revised 10 May 2013; accepted 17 May 2013

Copyright (C) 2013 Wei Hu. This is an open access article distributed under the Creative Commons Attribution License, which permits unrestricted use, distribution, and reproduction in any medium, provided the original work is properly cited.

\begin{abstract}
Avian influenza such as H5N1 could infect humans and cause great health concern due to its high mortality rate. In March 2013, a novel reassortant avianorigin influenza A (H7N9) virus was found in several patients with severe respiratory illness in China. Since then, at least 82 people in China have been infected with this new virus and 17 have died from this virus. The question of how these people were infected with this virus and whether this virus will spread among people remains an urgent topic for research. This study took an early investigation of this virus by comparing the collected viral genome sequences of 2013 H7N9 in China against those of previous avian H7N9 and examined the receptor binding specificity of this new virus. This virus was found to be very different from the previous avian H7N9 viruses and surprisingly many of the internal proteins of 2013 H7N9 from the avian and human hosts in China were either identical or similar. Our analysis of the HA protein of this virus implied that the current strains of 2013 H7N9 in China displayed avian type receptors as their primary binding preference and human type receptors as secondary. For pandemic risk assessment, we also detected 23 mutations, including a few well known for host adaptation, in the HA1 domain of the HA protein from this virus. Each mutation was quantified for its impact on the recaptor binding selection using a bioinformatics approach. Collectively these current mutations tended to decrease the HA binding affinity for avian type recaptors and increase that for human type receptors, which could enhance the ability of this virus to infect humans.
\end{abstract}

Keywords: H7N9; Influenza; Receptor Specificity; Mutation

\section{INTRODUCTION}

The discovery of a novel reassortant avian-origin influenza A (H7N9) virus from several patients in China in March 2013 signaled a major global public health concern [1]. This new virus is continuing its spread in China, raising the total number of people affected to at least 82 including 17 deaths as indicated in a news report from http://news.xinhuanet.com on April 17, 2013. In general human influenza tends to cause mild symptoms, but avian influenza such as $\mathrm{H} 5 \mathrm{~N}$ is more deadly for people. Human infections with avian influenza are most likely after direct contact with infected poultry. Avian H7N9 virus did not infect humans before March 2013 and certain gene mutations need to occur in order for it to acquire the capability to infect humans and spread between people. Because of the fast evolution rate of influenza, it is critical for us to closely monitor any evidence that 2013 H7N9 is passing from person to person, which could dramatically increase its pandemic potential.

The influenza A virus genome is made of eight gene segments that encode 10 proteins: HA, NA, PB1, PB2, PA, NP, M1, M2, NS1, NS2. The two surface proteins HA and NA are responsible for the entry of the virus into the host cells and release of new generation of viral particles from host cells respectively. The remaining eight proteins are internal proteins that have different functions ranging from facilitating the reproduction of the virus to providing structural support to the viral envelop. The segmented structure of genome makes it easier to form novel influenza viruses from reassortment of different influenza viruses. The study in [1] suggested that this novel 2013 H7N9 virus in China is of avian origin. Its NA gene is similar to that of another H7N9 virus from Korea (A/wild bird/Korea/A14/2011), its HA gene is close to that of an H7N3 virus from Zhejiang Province in China (A/duck/Zhejiang/12/2011), and all its internal gene segments are very similar to those from avian H9N2 viruses, particularly a virus isolated from a bram- 
bling in Beijing (A/brambling/Beijing/16/2012).

Although the host barrier for avian viruses to spread in humans needs further elucidation, the receptor binding specificity of HA is widely recognized as a major obstacle for direct avian to human transmission. In general, human influenza viruses tend to bind to SA $\alpha 2,6 \mathrm{Gal}$ receptors, whereas avian viruses favor SA $\alpha 2,3 \mathrm{Gal}$ recaptors. Adaptation of avian virus to humans likely requires a switch in receptor binding specificity of the virus from avian-type to human-type.

Inspired by the work in [1], which used three 2013 H7N9 strains collected from three patients in China, this study employed the methodology developed in [2-17] to investigate this novel avian-origin H7N9 virus with five 2013 H7N9 strains in China. Our aim was to discover gene sequence difference between this new virus and the previous avian H7N9 and identify and then analyze mutations in the HA protein that could help this virus making its adaptation from avian to human hosts.

\section{MATERTIALS AND METHDOS}

\subsection{Sequence Data}

Protein sequences of influenza viruses used in this study were retrieved from the EpiFlu Database

(http://platform.gisaid.org) of GISAID. All sequences were aligned with MAFFT [18] and phylogeny analysis of these sequences was conducted with MEGA [19]. The Meta information of the $2013 \mathrm{H} 7 \mathrm{~N} 9$ sequences in China is listed in Table 1. A/Hangzhou/1/2013 does not have all the 10 proteins as others in the sequence collection of 2013 H7N9 strains in China. The study in [1] utilized the first three viral genome sequences in Table $\mathbf{1}$ available at that time.

\subsection{Informational Spectrum Method}

The informational spectrum method (ISM) is a bioin- formatics technique that can be used to analyze protein sequences [20]. The idea is to translate the protein sequences into numerical sequences based on electron-ion interaction potential (EIIP) of each amino acid. Then the Discrete Fourier Transform (DFT) can be applied to these numerical sequences, and the resulting DFT coefficients are used to produce the energy density spectrum. The informational spectrum (IS) comprises the frequencies and the amplitudes of this energy density spectrum. According to the ISM theory, the peak frequencies of IS of a protein sequence reflect its biological or biochemical functions. The ISM was successfully applied to quantify the effects of HA mutations on the receptor binding preference in $[7,21,22]$.

\section{RESULTS}

\subsection{Sequence Comparison}

We compared five viral genome sequences of 2013 H7N9 in China with 13 sequences of previous avian H7N9 (Figure 1). It appeared that these five sequences

Table 1. Protein sequences of 2013 H7N9 in China.

\begin{tabular}{ll}
\hline ID & Protein \\
\hline A/Shanghai/1/2013 & $\begin{array}{l}\text { HA, NA, PB1, PB2, PA, NP, } \\
\text { M1, M2, NS1, and NS2 }\end{array}$ \\
A/Shanghai/2/2013 & $\begin{array}{l}\text { HA, NA, PB1, PB2, PA, NP, } \\
\text { M1, M2, NS1, and NS2 }\end{array}$ \\
A/Anhui/1/2013 & $\begin{array}{l}\text { HA, NA, PB1, PB2, PA, NP, } \\
\text { M1, M2, NS1, and NS2 }\end{array}$ \\
A/Hangzhou/1/2013 & HA \\
A/Chicken/Shanghai/S1053/2013 & $\begin{array}{l}\text { HA, NA, PB1, PB2, PA, NP, } \\
\text { M1, M2, NS1, and NS2 }\end{array}$ \\
A/Pigeon/Shanghai/S1069/2013 & $\begin{array}{l}\text { HA, NA, PB1, PB2, PA, NP, } \\
\text { M1, M2, NS1, and NS2 }\end{array}$ \\
\hline
\end{tabular}

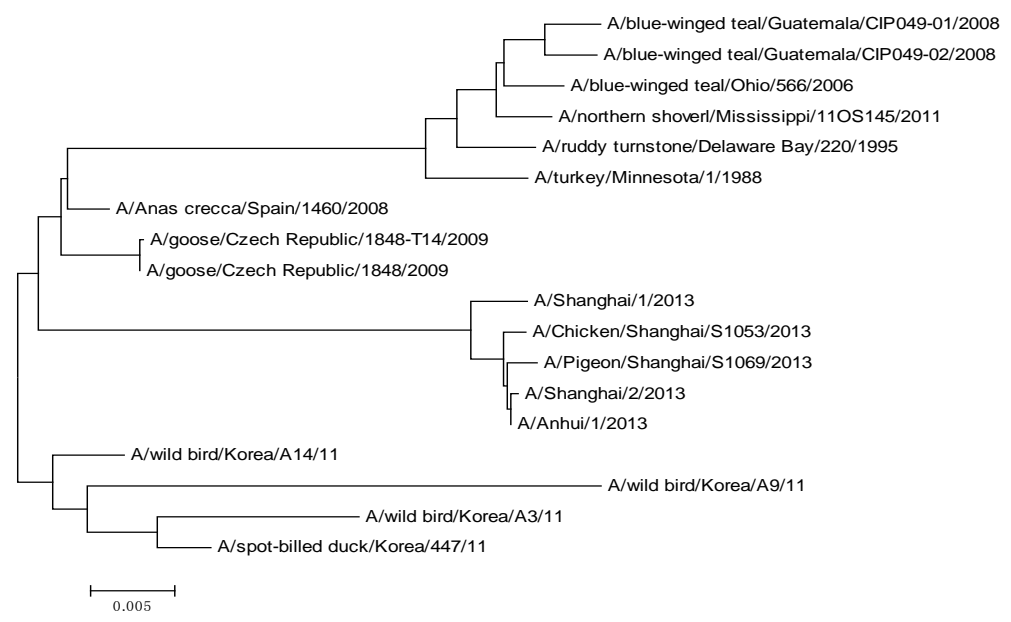

Figure 1. Polygenic tree of five viral genome sequences of 2013 H7N9 in China and those of previous avian H7N9. 
were quite very different from the previous avian H7N9 influenza. It was interesting to note that A/Shanghai/ $1 / 2013$, though a human strain, was not as similar to the other two human strains, A/Shanghai/2/2013 and A/Anhui/1/2013, as the two avian strains. In particular, A/ Shanghai/1/2013 and A/Shanghai/2/2013 were actually collected from the same city Shanghai.

We also compared the individual protein sequences of five 2013 H7N9 strains in China with that of the consensus sequence of 13 previous avian H7N9 strains as

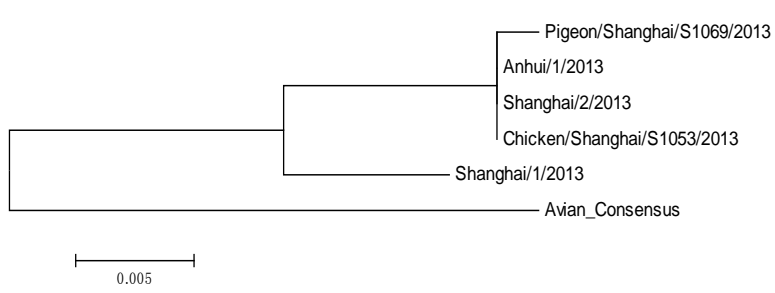

HA

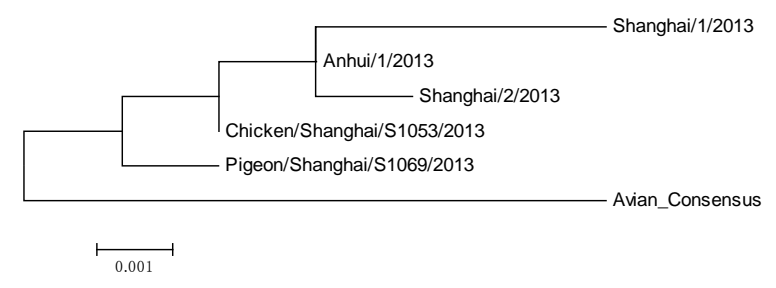

PB2

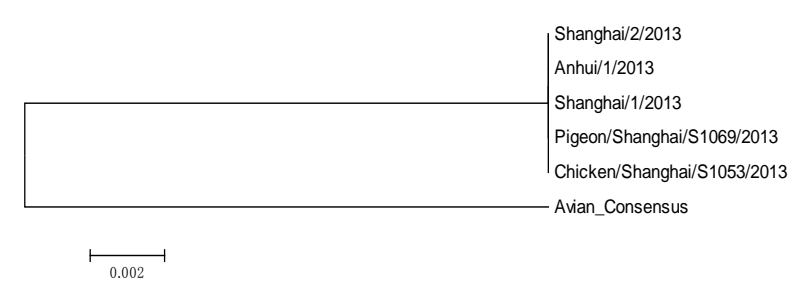

PA

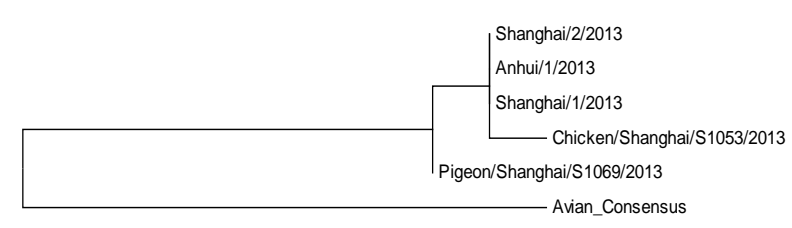

M1

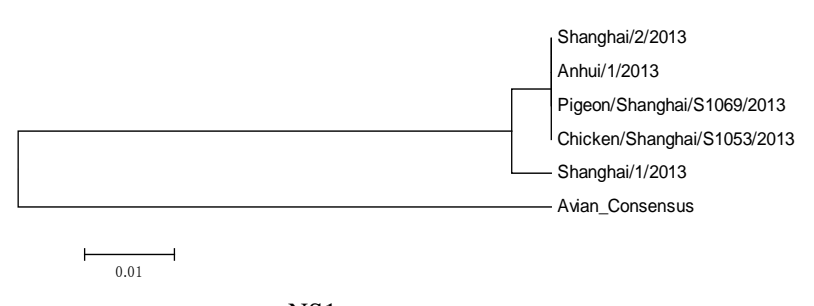

NS1 seen in Figure 1 (Figure 2).

The polygenic trees in Figure 2 implied that many of the internal proteins of avian and human 2013 H7N9 in China were either identical or similar, but remained very different from those of previous avian H7N9. The most diverse protein was the surface protein HA. There was a deletion in the stalk region of NA proteins [2] and a deletion at the $\mathrm{C}$ terminal of NS1 proteins of avian and human 2013 H7N9 in China as seen from the sequence display below (Table 2).

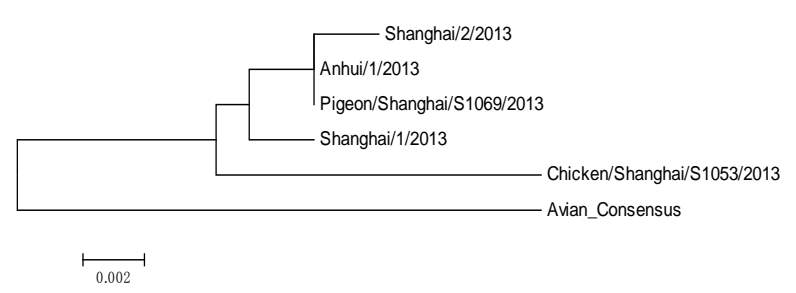

NA

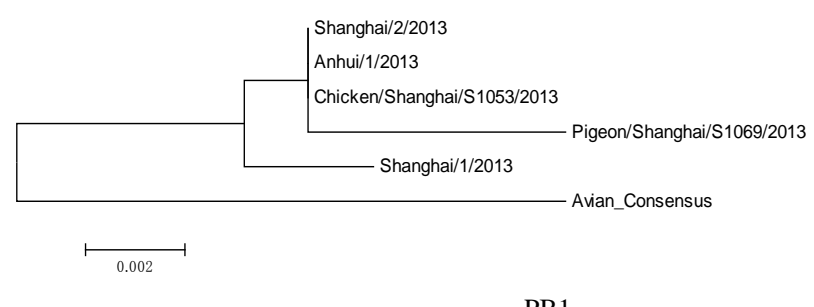

PB1

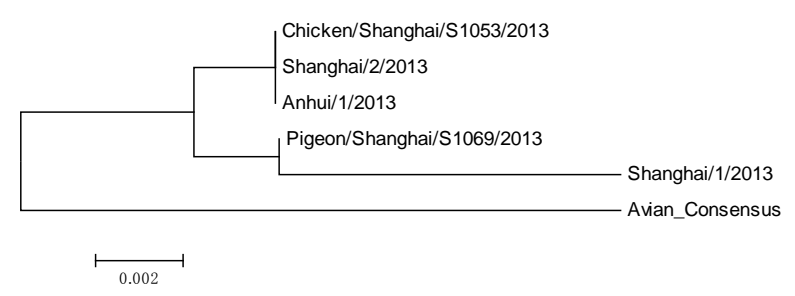

NP
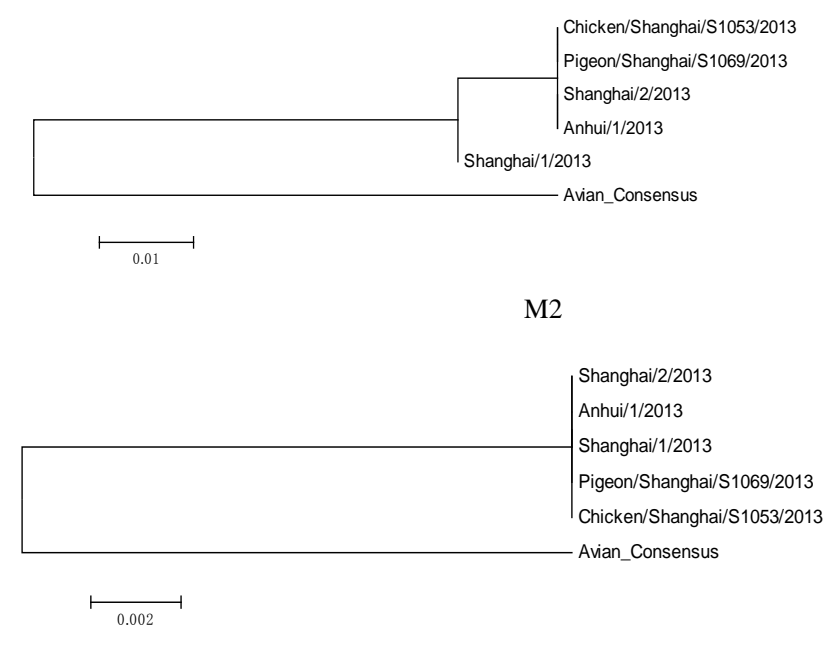

NS2

Figure 2. Polygenic trees of proteins of five 2013 H7N9 strains in China and those of the consensus of previous avian H7N9. 


\subsection{Receptor Affinity}

The HA protein of influenza is essential for the viral entry into the host cells and its receptor binding specificity is an important property of its function. In this part of study, we also included an extra HA protein sequence of 2013 H7N9 in China: A/Hangzhou/1/2013.

\subsubsection{Finding Mutations in the HA1 Domain of the HA Protein of 2013 H7N9 in China}

To render the whole picture and comparison of the sequences of HA1 of 2013 H7N9 in China with a consensus sequence made of previous avian H7N9, the alignment of them is presented in Table 3. Based on the sequence alignment, we were able to identify mutations in the HA1 domain of the HA protein of 2013 H7N9 in China (Tables 4 and 5). Two critical mutations T160A and Q226L were discovered in [1].

\subsubsection{Measuring the Effects of Mutations in HA on the Receptor Selection of 2013 H7N9 in China}

The ISM technique was applied to the mutations discovered in Section 3.2.1. We used 51 HA protein sequences of human H7 HA collected prior to 2013 to calculate the primary CIS frequency of $\mathrm{F}(0.328)$ and 13 HA protein sequences of avian H7N9 collected prior to 2013 to calculate the primary CIS frequency of $F(0.285)$. Therefore frequency $\mathrm{F}(0.328)$ was for binding human receptors whereas frequency $F(0.285)$ was for avian receptors. The primary and secondary CIS frequencies were identified for the four human HA proteins of 2013 H7N9 (Shanghai/1/2013, Shanghai/2/2013, Anhui/1/2013, and Hangzhou/1/2013) and the two avian HA proteins of 2013 H7N9 (Chicken/Shanghai/S1053/2013 and Pigeon/hanghai/S1069/2013), both of which were $F(0.285)$ and $\mathrm{F}(0.328)$. A study in [11] indicated that many influenza viruses tend to have dual receptor binding preference demonstrated by their primary and secondary CIS fre- quencies. Furthermore the IS of the HA protein of Hangzhou/1/2013 and that with a mutation I266Q were computed. To offer comparison with other H7 HA proteins, the IS of the HA protein of $\mathrm{A} /$ mallard/Netherlands/9/ 2005/H7N7 was also provided (Figure 3).

The net effect of mutation Q226I on the HA protein of Hangzhou/1/2013 was to change the IS amplitude at $\mathrm{F}(0.285)$ from 6.7662 to 6.9940 and that at $\mathrm{F}(0.326)$ from 6.4342 to 6.4703 . The HA1 sequences of Anhui/1/2013 and Hangzhou/1/2013 differed only at position 226, where the first has 226I and the second had 226L. Because EIIP value for both I and $\mathrm{L}$ is the same, mutation Q226L on Anhui/1/2013 had the same effect as mutation Q226I on Hangzhou/1/2013. Mutation Q226L is also known to be associated with transmission of avian H5N1 viruses by respiratory droplets in ferrets [23,24].

Besides Q226L, T160A was another mutation discovered in the HA protein of 2013 H7N9 in China [1]. A report from [25] suggested that double mutations S158N and T160A in the HA protein of H5N1 resulted in increased binding to human type receptors without a loss of binding to avian type receptors. Here we applied mutations S158N and T160A to Hangzhou/1/2013, and found that the IS amplitude at $\mathrm{F}(0.285)$ decreased by $0.0411(0.6 \%)$ and that at $\mathrm{F}(0.326)$ increased by 0.4136 (6.4\%). Our calculation thus showed that these two mutations had the same HA binding shift effect on Hangzhou/1/2013 as on the H5N1 virus.

Our next task was to calculate the IS amplitude change caused by each individual mutation found in Section 3.2.1 (Table 6). We selected the HA protein of Hangzhou/1/2013 as one representative of the six HA proteins of the avian and human 2013 H7N9 in China and applied these mutations to this HA protein. Collectively they tended to enhance the receptor affinity for human type receptors while reduce the affinity for avian type recaptors since the average IS amplitude change was -0.0988 $(1.41 \%)$ at $\mathrm{F}(0.295)$ and $0.0293(0.045 \%)$ at $\mathrm{F}(0.326)$.

Table 2. Deletion of NA and NS1 proteins from 2013 H7N9 in China when compared to those from previous avian H7N9.

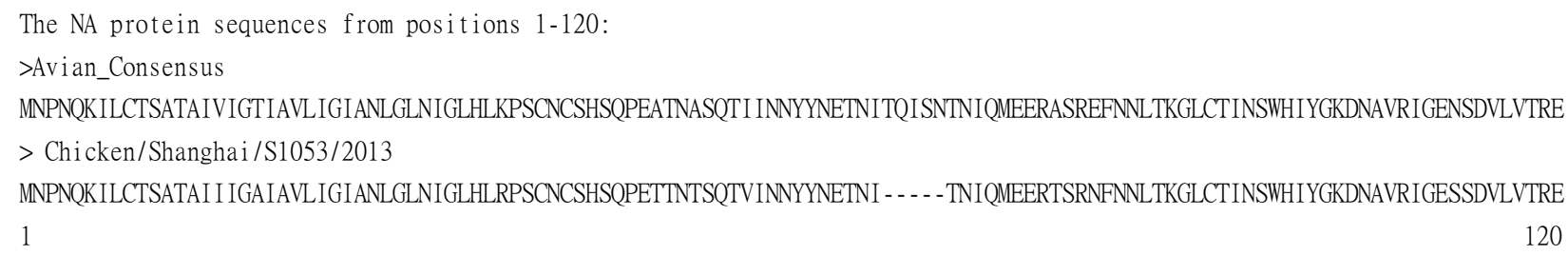

The whole NS1 protein sequences:

$>$ Avian_Consensus

MDSNTVSSFQVDCFLWHVRKRFADQELGDAPFLDRLRRDOKSLRGRGSTLGLDIETATRAGKQIVERILEEESDEALKMTIASVPASRYLTDMTLEEMSRDWFMLMPKQKVAGSLCIR MDQAIMDKNI ILKANFSVIFDRLETLILLRAFTEEGAIVGEISPLPSLPGHTDEDVKNAIGVLIGGLEWNDNTVRVSETLQRFAWRSSNEDGRPPLPPKQKRKMARTIESEV

$>$ Chicken/Shanghai/S1053/2013

MDSNTVSSFQVDCFLWHVRKRFADQEMGDAPFLDRLRRDQKSLRGRSSTLGLDIRTATREGKHIVERILEEESDEAFKMSIASVPAPRYLTDMTLEEMSRDWLMLIPKQKITGSLCIR MDQAIVDKNITLKANFSVIFNRLEALILLRAFTEEGAIVGEISPLPSLPGHTDKDVKNAIEILIGGFEWNDNTVRVSETLQRFAWRSSDEDGRSPLSTK - . . . . . . . . . . 
Table 3. Alignment of HA1 sequences of six 2013 H7N9 strains in China and the consensus HA1 sequence of previous avian H7N9.

Avian_Consensus DKICLGHHAVSNGTKVNTLTERGVEVVNATETVERTNVPRICSKGKRTVDLGQCGLLGTI Chicken/Shangha DKICLGHHAVSNGTKVNTLTERGVEVVNATETVERTNIPRICSKGKRTVDLGQCGLLGTI Pigeon/Shanghai DKICLGHHAVSNGTKVNTLTERGVEVVNATETVERTNIPRICSKGKRTVDLGQCGLLGTI Shanghai/1/2013 DKICLGHHAVSNGTKVNTLTERGVEVVNATETVERTNIPRICSKGKRTVDLGQCGLLGTI Shanghai/2/2013 DKICLGHHAVSNGTKVNTLTERGVEVVNATETVERTNIPRICSKGKRTVDLGQCGLLGTI Anhui/1/2013 DKICLGHHAVSNGTKVNTLTERGVEVVNATETVERTNIPRICSKGKRTVDLGQCGLLGTI Hangzhou/1/2013 DKICLGHHAVSNGTKVNTLTERGVEVVNATETVERTNIPRICSKGKRTVDLGQCGLLGTI $* * * * * * * * * * * * * * * * * * * * * * * * * * * * * * * * * * * * *: * * * * * * * * * * * * * * * * * * * * * *$

Avian_Consensus TGPPQCDQFLEFSADLIIERREGSDVCYPGKFVNEEALRQILRESGGIDKETMGFTYSGI Chicken/Shangha TGPPQCDQFLEFSADLIIERREGSDVCYPGKFVNEEALRQILRESGGIDKEAMGFTYSGI Pigeon/Shanghai TGPPQCDQFLEFSADLIIERREGSDVCYPGKFVNEEALRQILRESGGIDKEAMGFTYSGI Shanghai/1/2013 TGPPQCDQFLEFSADLIIERREGSDVCYPGKFVNEEALRQILRESGGIDKEAMGFTYSGI Shanghai/2/2013 TGPPQCDQFLEFSADLIIERREGSDVCYPGKFVNEEALRQILRESGGIDKEAMGFTYSGI Anhui/1/2013 TGPPQCDQFLEFSADLIIERREGSDVCYPGKFVNEEALRQILRESGGIDKEAMGFTYSGI Hangzhou/1/2013 TGPPQCDQFLEFSADLIIERREGSDVCYPGKFVNEEALRQILRESGGIDKEAMGFTYSGI

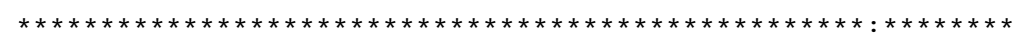

Avian_Consensus RTNGATSACRRSGSSFYAEMKWLLSNTDNAAFPQMTKSYKNPRNDPALIIWGIHHSGSTT Chicken/Shangha RTNGATSACRRSGSSFYAEMKWLLSNTDNAAFPQMTKSYKNTRKSPALIVWGIHHSVSTA Pigeon/Shanghai RTNGATSACRRSGSSFYAEMKWLLSNTDNAAFPQMTKSYKNTRKSPALIVWGIHHSVSTA Shanghai/1/2013 RTNGATSSCRRSGSSFYAEMKWLLSNTDNAAFPQMTKSYKNTRKNPALIVWGIHHSGSTA Shanghai/2/2013 RTNGATSACRRSGSSFYAEMKWLLSNTDNAAFPQMTKSYKNTRKSPALIVWGIHHSVSTA Anhui/1/2013 RTNGATSACRRSGSSFYAEMKWLLSNTDNAAFPQMTKSYKNTRKSPALIVWGIHHSVSTA Hangzhou/1/2013 RTNGATSACRRSGSSFYAEMKWLLSNTDNAAFPQMTKSYKNTRKSPALIVWGIHHSVSTA

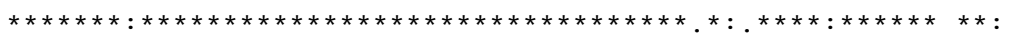

Avian_Consensus EQTKLYGSGSKLITVGSSNYQQSFVPSPGARPQVNGQSGRIDFHWLLLNPNDTVTFSFNG Chicken/Shangha EQTKLYGSGNKLVTVGSSNYQQSFVPSPGARPQVNGLSGRIDFHWLMLNPNDTVTFSFNG Pigeon/Shanghai EQTKLYGSGNKLVTVGSSNYQQSFVPSPGARPQVNGLSGRIDFHWLMLNPNDTITFSFNG Shanghai/1/2013 EQTKLYGSGNKLVTVGSSNYQQSFVPSPGARTQVNGQSGRIDFHWLMLNPNDTVTFSFNG Shanghai/2/2013 EQTKLYGSGNKLVTVGSSNYQQSFVPSPGARPQVNGLSGRIDFHWLMLNPNDTVTFSFNG Anhui/1/2013 EQTKLYGSGNKLVTVGSSNYQQSFVPSPGARPQVNGLSGRIDFHWLMLNPNDTVTFSFNG Hangzhou/1/2013 EQTKLYGSGNKLVTVGSSNYQQSFVPSPGARPQVNGISGRIDFHWLMLNPNDTVTFSFNG

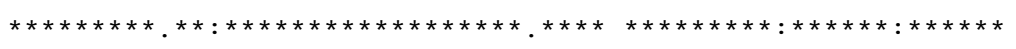

Avian_Consensus AFIAPDRASFLRGKSMGIQSGVQVDASCEGDCYHSGGTIISNLPFQNINSRAVGKCPRYV Chicken/Shangha AFIAPDRASFLRGKSMGIQSGVQVDANCEGDCYHSGGTIISNLPFQNIDSRAVGKCPRYV Pigeon/Shanghai AFIAPDRASFLRGKSMGIQSGVQVDANCEGDCYHSGGTIISNLPFQNIDSRAVGKCPRYV Shanghai/1/2013 AFIAPDRASFLRGKSMGIQSGVQVDADCEGDCYYSGGTIISNLPFQNIDSRAVGKCPRYV Shanghai/2/2013 AFIAPDRASFLRGKSMGIQSGVQVDANCEGDCYHSGGTIISNLPFQNIDSRAVGKCPRYV Anhui/1/2013 AFIAPDRASFLRGKSMGIQSGVQVDANCEGDCYHSGGTIISNLPFQNIDSRAVGKCPRYV Hangzhou/1/2013 AFIAPDRASFLRGKSMGIQSGVQVDANCEGDCYHSGGTIISNLPFQNIDSRAVGKCPRYV $* * * * * * * * * * * * * * * * * * * * * * * * * *, * * * * * *: * * * * * * * * * * * * * *: * * * * * * * * * * *$

Avian_Consensus KQESLMLATGMKNVPENPKGR Chicken/Shangha KQRSLLLATGMKNVPEIPKGR Pigeon/Shanghai KQRSLLLATGMKNVPEIPKGR Shanghai/1/2013 KQRSLLLATGMKNVPEIPKGR Shanghai/2/2013 KQRSLLLATGMKNVPEIPKGR Anhui/1/2013 KQRSLLLATGMKNVPEIPKGR Hangzhou/1/2013 KQRSLLLATGMKNVPEIPKGR $* * . * *: * * * * * * * * * * * * * *$ 
Table 4. Amino acids at critical sites (H3 numbering) for receptor selection in the HA protein. The distances in the table represent the Hamming distances between the consensus of HA sequences of previous avian H7N9 and others based on the amino acids at the 17 sites in the table.

\begin{tabular}{|c|c|c|c|c|c|c|c|c|c|}
\hline Position & 98 & 136 & 153 & 183 & 186 & 190 & 193 & 194 & 195 \\
\hline H1N1 human consensus & $\mathrm{Y}$ & S & $\mathrm{W}$ & $\mathrm{H}$ & $\mathrm{P}$ & $\mathrm{D}$ & A & $\mathrm{L}$ & $\mathrm{Y}$ \\
\hline H1N1 California/04/2009 & $\mathrm{Y}$ & $\mathrm{T}$ & $\mathrm{W}$ & $\mathrm{H}$ & S & $\mathrm{D}$ & S & $\mathrm{L}$ & $\mathrm{Y}$ \\
\hline H5N1 human consensus & $\mathrm{Y}$ & $\mathrm{T}$ & $\mathrm{W}$ & $\mathrm{H}$ & $\mathrm{N}$ & $\mathrm{E}$ & $\mathrm{K}$ & $\mathrm{L}$ & $\mathrm{Y}$ \\
\hline H7N9 avian consensus & $\mathrm{Y}$ & $\mathrm{T}$ & $\mathrm{W}$ & $\mathrm{H}$ & G & $\mathrm{E}$ & $\mathrm{K}$ & $\mathrm{L}$ & $\mathrm{Y}$ \\
\hline Chicken/Shanghai/S1053/2013 & $\mathrm{Y}$ & $\mathrm{T}$ & $\mathrm{W}$ & $\mathrm{H}$ & V & $\mathrm{E}$ & $\mathrm{K}$ & $\mathrm{L}$ & $\mathrm{Y}$ \\
\hline Pigeon/Shanghai/S1069/2013 & $\mathrm{Y}$ & $\mathrm{T}$ & $\mathrm{W}$ & $\mathrm{H}$ & V & E & K & $\mathrm{L}$ & $\mathrm{Y}$ \\
\hline Shanghai/1/2013 & $\mathrm{Y}$ & $\mathrm{T}$ & W & $\mathrm{H}$ & G & E & $\mathrm{K}$ & $\mathrm{L}$ & $\mathrm{Y}$ \\
\hline Shanghai/2/2013 & $\mathrm{Y}$ & $\mathrm{T}$ & $\mathrm{W}$ & $\mathrm{H}$ & $\mathrm{V}$ & $\mathrm{E}$ & $\mathrm{K}$ & $\mathrm{L}$ & $\mathrm{Y}$ \\
\hline Anhui/1/2013 & $\mathrm{Y}$ & $\mathrm{T}$ & $\mathrm{W}$ & $\mathrm{H}$ & V & $\mathrm{E}$ & K & $\mathrm{L}$ & $\mathrm{Y}$ \\
\hline Hangzhou/1/2013 & $\mathrm{Y}$ & $\mathrm{T}$ & $\mathrm{W}$ & $\mathrm{H}$ & V & $\mathrm{E}$ & $\mathrm{K}$ & $\mathrm{L}$ & $\mathrm{Y}$ \\
\hline Position & 196 & 216 & 221 & 222 & 225 & 226 & 227 & 228 & Dist \\
\hline H1N1 human consensus & $\mathrm{H}$ & $\mathrm{E}$ & $\mathrm{P}$ & $\mathrm{K}$ & $\mathrm{D}$ & Q & E & G & 9 \\
\hline H1N1 California/04/2009 & $\mathrm{Q}$ & E & $\mathrm{P}$ & $\mathrm{K}$ & $\mathrm{D}$ & Q & E & G & 8 \\
\hline H5N1 human consensus & $\mathrm{Q}$ & K & S & K & G & $\mathrm{Q}$ & S & G & 4 \\
\hline H7N9 avian consensus & G & S & $P$ & $\mathrm{Q}$ & G & $\mathrm{Q}$ & S & G & 0 \\
\hline Chicken/Shanghai/S1053/2013 & G & S & $\mathrm{P}$ & $\mathrm{Q}$ & G & $\mathrm{L}$ & S & G & 2 \\
\hline Pigeon/Shanghai/S1069/2013 & G & S & $\mathrm{P}$ & Q & G & $\mathrm{L}$ & S & G & 2 \\
\hline Shanghai/1/2013 & G & S & $\mathrm{T}$ & Q & G & Q & S & G & 1 \\
\hline Shanghai/2/2013 & G & S & $\mathrm{P}$ & $\mathrm{Q}$ & G & $\mathrm{L}$ & S & G & 2 \\
\hline Anhui/1/2013 & G & $\mathrm{S}$ & $P$ & Q & G & $\mathrm{L}$ & S & G & 2 \\
\hline Hangzhou/1/2013 & G & S & $\mathrm{P}$ & $\mathrm{Q}$ & G & I & S & G & 2 \\
\hline
\end{tabular}

Table 5. Additional mutations found in the HA proteins of 2013 H7N9 in China.

\begin{tabular}{|c|c|c|c|c|c|c|c|c|c|c|}
\hline Position & 47 & 122 & 138 & 171 & 173 & 174 & 179 & 186 & 189 & 199 \\
\hline H7N9 avian consensus & V & $\mathrm{T}$ & A & $\mathrm{P}$ & $\mathrm{N}$ & $\mathrm{D}$ & I & G & $\mathrm{T}$ & S \\
\hline Chicken/Shanghai/S1053/2013 & I & A & A & $\mathrm{T}$ & K & S & $\mathrm{V}$ & $\mathrm{V}$ & A & $\mathrm{N}$ \\
\hline Pigeon/Shanghai/S1069/2013 & I & A & A & $\mathrm{T}$ & $\mathrm{K}$ & S & $\mathrm{V}$ & $\mathrm{V}$ & A & $\mathrm{N}$ \\
\hline Shanghai/1/2013 & I & A & S & $\mathrm{T}$ & $\mathrm{K}$ & $\mathrm{N}$ & $\mathrm{V}$ & G & A & $\mathrm{N}$ \\
\hline Shanghai/2/2013 & I & A & A & $\mathrm{T}$ & $\mathrm{K}$ & S & $\mathrm{V}$ & $\mathrm{V}$ & A & $\mathrm{N}$ \\
\hline Anhui/1/2013 & I & A & A & $\mathrm{T}$ & $\mathrm{K}$ & S & $\mathrm{V}$ & $\mathrm{V}$ & A & $\mathrm{N}$ \\
\hline Hangzhou/1/2013 & I & A & A & $\mathrm{T}$ & $\mathrm{K}$ & S & $\mathrm{V}$ & $\mathrm{V}$ & A & $\mathrm{N}$ \\
\hline Position & 202 & 221 & 236 & 243 & 277 & 283 & 298 & 312 & 315 & 326 \\
\hline H7N9 avian consensus & I & $\mathrm{P}$ & $\mathrm{L}$ & V & $\mathrm{S}$ & $\mathrm{H}$ & $\mathrm{N}$ & E & M & $\mathrm{N}$ \\
\hline Chicken/Shanghai/S1053/2013 & V & $\mathrm{P}$ & M & $\mathrm{V}$ & $\mathrm{N}$ & $\mathrm{H}$ & $\mathrm{D}$ & $\mathrm{R}$ & $\mathrm{L}$ & I \\
\hline Pigeon/Shanghai/S1069/2013 & V & $\mathrm{P}$ & M & I & $\mathrm{N}$ & $\mathrm{H}$ & $\mathrm{D}$ & $\mathrm{R}$ & $\mathrm{L}$ & I \\
\hline Shanghai/1/2013 & V & $\mathrm{T}$ & M & V & $\mathrm{D}$ & $\mathrm{Y}$ & $\mathrm{D}$ & $\mathrm{R}$ & $\mathrm{L}$ & I \\
\hline Shanghai/2/2013 & V & $\mathrm{P}$ & M & V & $\mathrm{N}$ & $\mathrm{H}$ & $\mathrm{D}$ & $\mathrm{R}$ & L & I \\
\hline Anhui/1/2013 & V & $\mathrm{P}$ & M & $\mathrm{V}$ & $\mathrm{N}$ & $\mathrm{H}$ & $\mathrm{D}$ & $\mathrm{R}$ & $\mathrm{L}$ & I \\
\hline Hangzhou/1/2013 & V & $\mathrm{P}$ & M & V & $\mathrm{N}$ & $\mathrm{H}$ & D & $\mathrm{R}$ & $\mathrm{L}$ & I \\
\hline
\end{tabular}



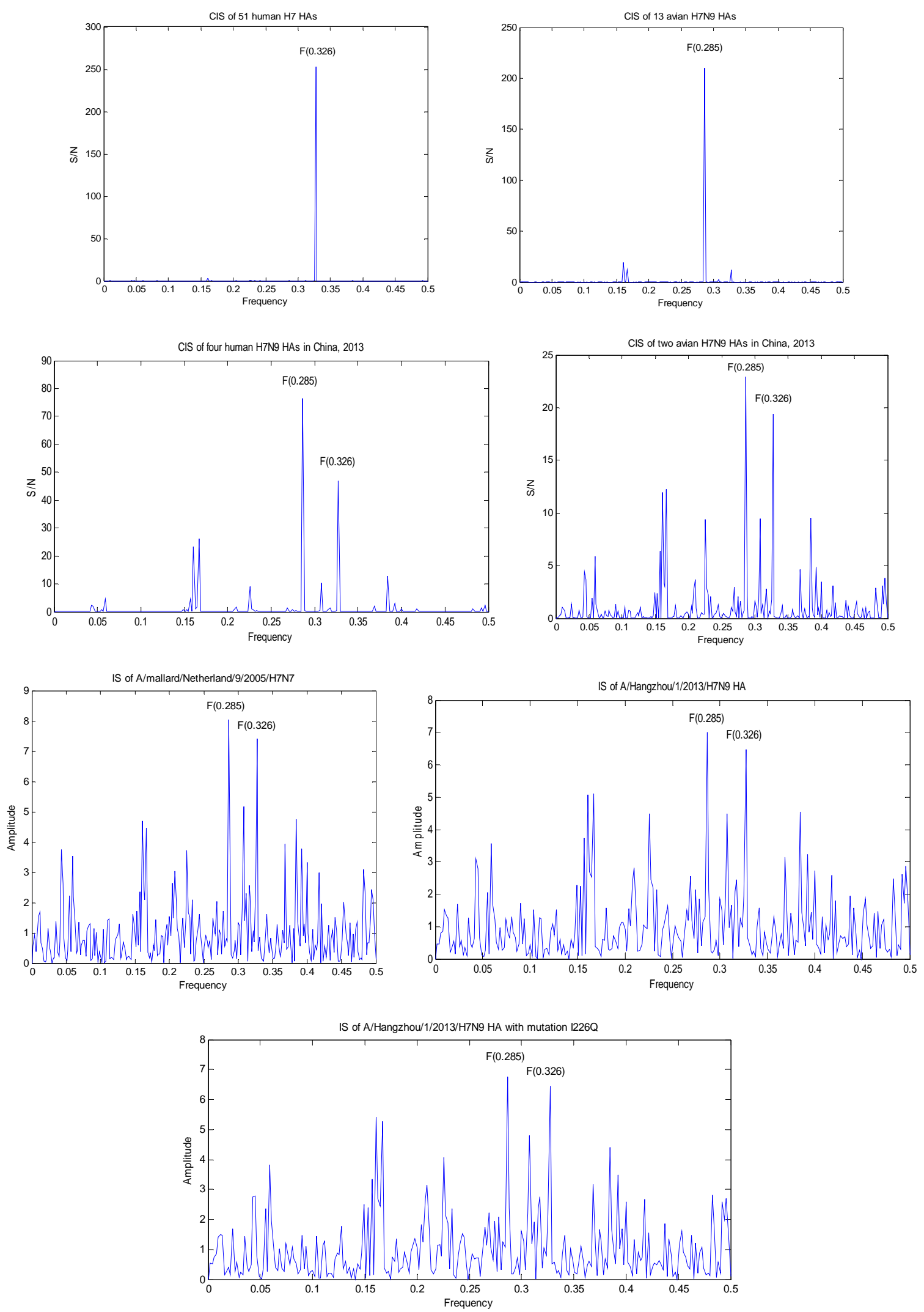

Figure 3. CIS of 51 human H7 HA proteins, CIS of 13 avian H7N9 HA proteins, CIS of four HA proteins of human 2013 H7N9 in China, CIS of two HA proteins of avian 2013 H7N9 in China, IS of the HA protein of A/Hangzhou/ $1 / 2013$ and IS of that with mutation I226Q, and IS of the HA protein of A/mallard/Netherlands/9/2005/H7N7. 
Table 6. Calculation of the IS amplitude change of HA of A/Hangzhou/1/2013 caused by the mutations at the primary and second binding frequencies.

\begin{tabular}{|c|c|c|}
\hline Mutation & IS amplitude change at $\mathrm{F}(0.285)$ & IS amplitude change at $F(0.326)$ \\
\hline V47I & 0.0219 & -0.0357 \\
\hline $\mathrm{T} 122 \mathrm{~A}$ & 0.0667 & -0.3675 \\
\hline A138S & 0.1081 & -0.011 \\
\hline $\mathrm{P} 171 \mathrm{~T}$ & 0.5041 & -0.2764 \\
\hline N173K & -0.2044 & 0.2477 \\
\hline D174S & -0.1129 & 0.1636 \\
\hline D174N & 0.3165 & -0.2028 \\
\hline $\mathrm{I} 179 \mathrm{~V}$ & 0.0003 & 0.043 \\
\hline G186V & $1 \mathrm{E}-04$ & 0.0018 \\
\hline T189A & -0.266 & -0.1016 \\
\hline S199N & -0.5828 & 0.5208 \\
\hline $\mathrm{I} 202 \mathrm{~V}$ & 0.0266 & -0.0318 \\
\hline P221T & 0.0103 & 0.35 \\
\hline Q226I & 0.2278 & 0.0361 \\
\hline L236M & -0.5944 & -0.5721 \\
\hline V243I & -0.0352 & 0.0211 \\
\hline S277N & -0.7631 & 0.7874 \\
\hline S277D & -0.5364 & 0.4789 \\
\hline H283Y & -0.1853 & -0.1261 \\
\hline N298D & 0.1449 & -0.0874 \\
\hline E312R & 0.1755 & -0.2925 \\
\hline M315L & -0.5832 & 0.1453 \\
\hline N326I & -0.0135 & -0.0223 \\
\hline Average & -0.0988 & 0.0293 \\
\hline
\end{tabular}

To visualize the impact of these mutations, we plotted the numerical values of IS amplitude change in Figure 4. Mutations S199N, S277N, and S277D clearly favored human receptor binding and reduced avian receptor binding and all of these three mutations mutated the amino acid S. The famous mutation Q226I also found in [1] only generated moderate change that increased both human and avian receptor binding. Another interesting mutation was L236M that reduced both of avian and human binding greatly.

\section{CONCLUSION}

The present study made use of the current available viral genome sequences of 2013 H7N9 in China. Our goal was to make an early investigation of this novel virus. Se- quence comparison revealed that this new virus was quite different from previous avian H7N9, but many of the internal proteins of 2013 H7N9 in China were either identical or similar. For pandemic risk assessment, the HA protein of this new virus was examined due to its critical role in the adaptation to human hosts. Our analysis implied that the current strains of 2013 H7N9 in China exhibited avian type receptors as their primary binding preference and human type receptors as secondary. We found 23 mutations in the HA1 domain of the HA protein of this virus. Each of these mutations was measured for its effect on receptor selection. Three mutations S199N, S277N, and S277D in the HA protein of 2013 H7N9 in China showed evident power to increase the binding affinity for human type receptors and at the 
IS amplitude change of $A /$ Hangzhou/1/2013 caused by mutations

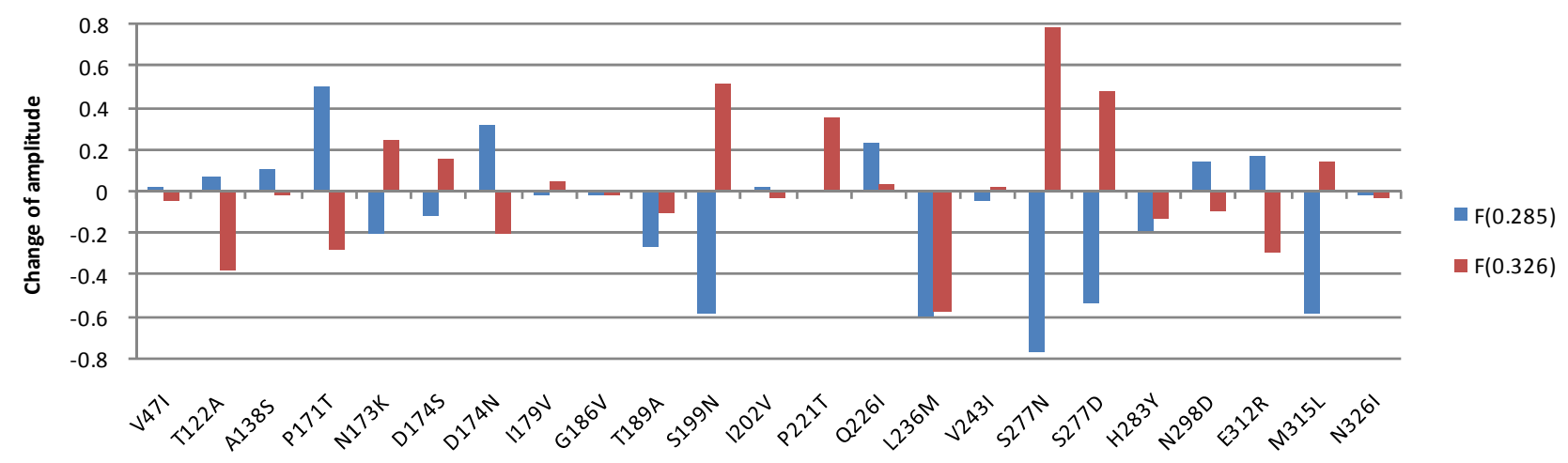

Figure 4. IS amplitude change of A/Hangzhou/1/2013 caused by 23 mutations in the HA proteins of 2013 H7N9 in China.

same time to reduce the affinity for avian type receptors. Collectively these mutations enhanced the binding to human type receptors whereas decreased the binding to avian type. Our findings suggested the current mutation pattern of this new virus contributed to its continued adaptation to human hosts.

\section{ACKNOWLEDGEMENTS}

We thank Houghton College for its financial support.

\section{REFERENCES}

[1] Gao, R.B., Cao, B., Hu, Y.W., Feng, Z.J., et al. (2013) Human infection with a novel avian-origin influenza A (H7N9) virus. The New England Journal of Medicine.

[2] Hu, W. (2009) Analysis of correlated mutations, stalk motifs, and phylogenetic relationship of the 2009 influenza A virus neuraminidase sequences. Journal of Biomedical Science and Engineering, 2, 550-558. doi:10.4236/jbise.2009.27080

[3] Hu, W. (2010) The interaction between the 2009 H1N1 Influenza A hemagglutinin and neuraminidase: Mutations, co-mutations, and the NA stalk motifs. Journal of Biomedical Science and Engineering, 3, 1-12. doi:10.4236/jbise.2010.31001

[4] Hu, W. (2010) Novel host markers in the 2009 pandemic H1N1 influenza A virus. Journal of Biomedical Science and Engineering, 3, 584-601. doi:10.4236/jbise.2010.36081

[5] Hu, W. (2010) Nucleotide host markers in the influenza A viruses. Journal of Biomedical Science and Engineering, 3, 684-699. doi:10.4236/jbise.2010.37093

[6] Hu, W. (2010) Identification of highly conserved domains in hemagglutinin associated with the receptor binding specificity of influenza viruses: 2009 H1N1, avian H5N1, and swine H1N2. Journal of Biomedical Science and Engineering, 3, 114-123. doi:10.4236/jbise.2010.32017

[7] $\mathrm{Hu}, \mathrm{W}$. (2010) Quantifying the effects of mutations on receptor binding specificity of influenza viruses. Journal of Biomedical Science and Engineering, 3, 227-240. doi:10.4236/jbise.2010.33031

[8] Hu, W. (2010) Subtle differences in receptor binding specificity and gene sequences of the 2009 pandemic H1N1 influenza virus. Advances in Bioscience and Biotechnology, 1, 305-314. doi:10.4236/abb.2010.14040

[9] Hu, W. (2010) Correlated mutations in the four influenza proteins essential for viral RNA synthesis, host adaptation, and virulence: NP, PA, PB1, and PB2. Natural Science, 2, 1138-1147. doi:10.4236/ns.2010.210141

[10] King, D., Miller, Z., Jones, W. and Hu, W. (2010) Characteristic sites in the internal proteins of avian and human influenza viruses. Journal of Biomedical Science and Engineering, 3, 943-955. doi:10.4236/jbise.2010.310125

[11] Hu, W. (2010) Highly conserved domains in hemagglutinin of influenza viruses characterizing dual receptor binding. Natural Science, 2, 1005-1014. doi:10.4236/ns.2010.29123

[12] Hu, W. (2010) Host markers and correlated mutations in the overlapping genes of influenza viruses: M1, M2; NS1, NS2; and PB1, PB1-F2. Natural Science, 2, 1225-1246. doi:10.4236/ns.2010.211150

[13] Hu, W. (2011) Receptor binding specificity and origin of 2009 H1N1 pandemic influenza virus. Natural Science, 3, 234-248. doi:10.4236/ns.2011.33030

[14] Hu, W. (2011) New mutational trends in the HA protein of 2009 H1N1 pandemic influenza virus from May 2010 to February 2011. Natural Science, 3, 379-387. doi:10.4236/ns.2011.35051

[15] Hu, W. (2011) Characterization of Asian and North American Avian H5N1. American Journal of Molecular Biology, 1, 52-61. doi:10.4236/ajmb.2011.12007

[16] Hu, W. (2012) Molecular features of highly pathogenic avian and human H5N1 influenza A viruses in Asia. Computational Molecular Bioscience, 2, 45-59. doi:10.4236/cmb.2012.22005

[17] Hu, W. (2012) Molecular determinants for receptor binding in hemagglutinin protein of 2009 pandemic H1N1. Proceedings of 6th International Conference Bioinformatics and Biomedical Engineering, Shanghai, 17-20 May 2012, 629-632.

[18] Katoh, K., Kuma, K., Toh, H. and Miyata, T. (2005) 
MAFFT version 5: Improvement in accuracy of multiple sequence alignment. Nucleic Acids Research, 33, 511-518. doi:10.1093/nar/gki198

[19] Tamura, K., Peterson, D., Peterson, N., Stecher, G., Nei, M. and Kumar, S. (2011) MEGA5: Molecular evolutionary genetics analysis using maximum likelihood, evolutionary distance, and maximum parsimony methods. Molecular Biology and Evolution, 28, 2731-2739. doi:10.1093/molbev/msr121

[20] Cosic, I. (1997) The resonant recognition model of macromolecular bioreactivity, theory and application. Birkhauser Verlag, Berlin. doi:10.1007/978-3-0348-7475-5

[21] Veljkovic, V., Niman, H.L., Glisic, S., Veljkovic, N., Perovic, V. and Muller, C.P. (2009) Identification of hemagglutinin structural domain and polymorphisms which may modulate swine H1N1 interactions with human receptor. BMC Structural Biology, 9, 62. doi:10.1186/1472-6807-9-62

[22] Veljkovic, V., Veljkovic, N., Muller, C.P., Müller, S., Glisic, S., Perovic, V. and Köhler, H. (2009) Characteri- zation of conserved properties of hemagglutinin of H5N1 and human influenza viruses: Possible consequences for therapy and infection control. BMC Structural Biology, 7, 9-21.

[23] Imai, M., Watanabe, T., Hatta, M., et al. (2012) Experimental adaptation of an influenza H5 HA confers respiratory droplet transmission to a reassortant H5 HA/H1N1 virus in ferrets. Nature, 486, 420-428.

[24] Herfst, S., Schrauwen, E.J., Linster, M., et al. (2012) Airborne transmission of influenza A/H5N1 virus between ferrets. Science, 336, 1534-1541. doi:10.1126/science.1213362

[25] Wang, W., Lu, B., Zhou, H., Suguitan Jr., A.L., Cheng, X., Subbarao, K., Kemble, G. and Jin, H. (2010) Glycosylation at $158 \mathrm{~N}$ of the hemagglutinin protein and recaptor binding specificity synergistically affect the antigenicity and immunogenicity of a live attenuated H5N1 A/ Vietnam/1203/2004 vaccine virus in ferrets. Journal of Virology, 84, 6570-6577. doi:10.1128/JVI.00221-10 